\title{
Correction to: Reliable benchmarking: requirements and solutions
}

\author{
Dirk Beyer $^{1} \cdot$ Stefan Löwe ${ }^{2} \cdot$ Philipp Wendler ${ }^{1}$
}

Published online: 21 February 2022

(c) The Authors 2020

\section{Correction to: Int J Softw Tools Technol Transfer (2019) 21:1-29 https://doi.org/10.1007/s10009-017-0469-y}

The article "Reliable benchmarking: requirements and solutions", written by Dirk Beyer, Stefan Löwe, and Philipp Wendler, was originally published electronically on the publisher's Internet portal on November 3, 2017 without open access. With the author(s)' decision to opt for Open Choice, the copyright of the article changed on December 6, 2020 to (C) The Authors 2021 and the article is forthwith distributed under a Creative Commons Attribution.
The original article can be found online at https://doi.org/ 10.1007/s 10009-017-0469-y.

Publisher's Note Springer Nature remains neutral with regard to jurisdictional claims in published maps and institutional affiliations.
The original article can be found online at https://doi.org/10.1007/ s10009-017-0469-y.

\footnotetext{
Philipp Wendler

benchmarking@sosy-lab.org

LMU Munich, Munich, Germany

2 One Logic, Passau, Germany
} 